Vol. 13 (2004): 54-67.

\title{
Contents of trichothecenes in oats during official variety, organic cultivation and nitrogen fertilization trials in Finland
}

\author{
Veli Hietaniemi \\ MTT Agrifood Research Finland, Chemistry laboratory, FIN-31600 Jokioinen, Finland, \\ e-mail:veli.hietaniemi@mtt.fi \\ Markku Kontturi \\ MTT Agrifood Research Finland, Plant Production Research, FIN-31600 Jokioinen, Finland \\ Sari Rämö, Merja Eurola \\ MTT Agrifood Research Finland, Chemistry Laboratory, FIN-31600 Jokioinen, Finland \\ Arjo Kangas, Markku Niskanen \\ MTT Agrifood Research Finland, South Ostrobothnia Research Station, FIN-31600 Jokioinen, Finland \\ Marketta Saastamoinen \\ Satafood Development Association, Risto Rytin katu 70 C, FIN-32700 Huittinen, Finland
}

\begin{abstract}
Natural toxins, such as mycotoxins, have emerged as a significant factor affecting the safety image of cereal grains as a raw material for the food and feed industry. The aim of the present study was to investigate the contents of trichothecenes in representative samples of oats during official variety, nitrogen fertilization and organic farming trials in Finland, 1997-1999. Further objectives were to promote industry and commerce by selection of high-quality oat varieties for various applications. The official variety trials conducted at 8-10 locations were managed following standard protocol. There were 2 types of agronomy trial, the first included comparison of oat cultivars grown in conventional and organic farming systems at 6 locations, and the second used 5 nitrogen rates $(0,40,80,120$ and $160 \mathrm{~kg} \mathrm{~N} \mathrm{ha}^{-1}$ ) at 2 locations. Regardless of wet cold summer occurring in Finland during 1998, the concentrations of Fusarium toxins were lowest during this 3 year monitoring period. More mycotoxins were produced during the warm, dry summers of 1997 and 1999 than in 1998. In all, 55\% of the oat samples in the official variety trials contained deoxynivalenol (DON) within the range of 50$896 \mu \mathrm{g} \mathrm{kg}^{-1}$. The differences in DON concentrations between organic and conventional cultivation were small. The results showed also that the use of various nitrogen fertilization levels only slightly affected the trichothecene concentrations. The contents of trichothecenes in Finnish grains appeared to be similar to or lower than those reported earlier in the Northern Hemisphere.
\end{abstract}

Key words: oats, grains, mycotoxins, trichothecenes, Fusarium toxins, official variety trials, nitrogen, organic farming, cultivars 
Vol. 13 (2004): 54-67.

\section{Introduction}

The central goal of grain cultivation is the production of high-quality food or feed-related raw materials for the processing industry. Natural toxins, such as mycotoxins, have emerged as a significant factor affecting the safety image of cereal grains as a raw material for the food and feed industry. Many previous studies in Finland (Karppanen et al. 1985, Hietaniemi and Kumpulainen 1991, 1993, Rizzo 1993, Eskola et al. 2001, Rizzo et al. 2001) and other European countries (Tanaka et al. 1988, Langseth et al. 1989, 1999, Müller and Schwadorf 1993, Pettersson et al. 1995, Rizzo et al. 2001, Widestrand 2001, Döll et al. 2002, Schollenberger et al. 2002) as well as globally (Tanaka et al. 1988, Shephard et al. 1996, Groves et al. 1999, Janardhana et al. 1999, Salay and Mercadante 2002) have shown that there is reason to focus on Fusarium toxins and their appearance. A planned European Union directive will specify the maximum limits for trichothecenes such as 4-deoxynivalenol (DON), T-2 toxin and HT-2 toxin and for zearalenone (ZEN) and fumonisins. DON is the most frequently found contaminant of oats, barley, wheat and corn throughout the world (Scott 1989, WHO 1993, 2001). In addition to DON, T-2 toxin, HT-2 toxin and ZEN frequently occur in cereal crops cultivated in northern temperate regions (Hietaniemi and Kumpulainen 1991, Pettersson et al. 1995, Langseth et al. 1999, Rizzo et al. 2001, Thuvander et al. 2001, Eskola 2002, Lígia Martins and Martins 2002). On the other hand, fumonisins cause more extensive problems in the Southern Hemisphere than in the Northern (Shephard et al. 1996). The most frequently isolated Fusarium species are $F$. graminearum, F. culmorum, F. moniliforme, $F$. poae, F. equiseti and $F$. proliferatum (Ylimäki et al. 1979, Marasas et al. 1984, Hietaniemi and Kumpulainen 1991, Eriksen and Alexander 1998, Eskola et al. 2001, Creppy 2002).

Numerous studies on mould toxicoses have shown that type A trichothecenes such as T-2 toxin, HT-2 toxin, diacetoxyscirpenol (DAS) and neosolaniol are more acutely toxic, whereas type $\mathrm{B}$ trichothecenes such as DON and nivalenol (NIV) are less toxic and are therefore implicated in more chronic toxicoses (Atroshi et al. 2002, Creppy 2002, Gutleb et al. 2002, Vilà et al. 2002, de Vries et al. 2003, Sudakin 2003). For example, the most frequently found of these substances (DON) in cereal crops is known to affect symptoms of intoxication in humans such as abdominal pain or a feeling of fullness in the abdomen, dizziness, headache, throat irritation, nausea, vomiting, diarrhoea, and blood in the stool (Eriksen and Alexander 1998). In the case of intoxication in animals, symptoms such as loss of appetite, reduced weight gain, vomiting, heavy diarrhoea and swelling have been reported (Joffe 1978, Ueno 1987). In addition, DON is a very stable compound occurring during both storage and processing of food and does not degrade at high temperatures (Scott 1991).

Increased attention has been focused on mycotoxins in Finland, especially the late 1980s, Hietaniemi and Kumpulainen (1991) showed that almost all grain and feed samples studied in Finland during 1987-1988 contained from 7 to $300 \mu \mathrm{g} \mathrm{kg}^{-1}$ of DON and smaller amounts (13$120 \mu \mathrm{g} \mathrm{kg}^{-1}$ ) of 3-acetyldeoxynivalenol. The most toxic trichothecenes, T-2- and HT-2 toxin, as well as NIV and ZEN, were found at low concentrations in some samples. Based on the results of Rizzo (1993) trichothecene concentrations in Finnish grains $(n=292)$ have ranged $1-6300 \mu \mathrm{g}$ $\mathrm{kg}^{-1}$ for DON, $1-1000 \mu \mathrm{g} \mathrm{kg}^{-1}$ for NIV and 5$238 \mu \mathrm{g} \mathrm{kg}^{-1}$ for T-2. In the study of Eskola et al. (2002) DON was detected in 54 of 68 Finnish cereal samples in the concentration range 5-111 $\mu \mathrm{g} \mathrm{kg}^{-1}$. NIV and HT-2 toxin were detected in 3 and 2 samples, respectively, in the concentration range 10-20 $\mu \mathrm{g} \mathrm{kg}^{-1}$. In addition, Eskola et al. reported the contents of Fusarium toxins in 47 cereal grain samples collected in different parts of the country. The mean concentrations of DON, 3-AcDON, NIV, HT-2 and ZEN in contaminated samples were 60,30, 42, 43 and $5 \mu \mathrm{g} \mathrm{kg}^{-1}$, respectively. T-2 was detected only once $(23 \mu \mathrm{g}$ $\left.\mathrm{kg}^{-1}\right)$, while fusarenon $\mathrm{X}(\mathrm{FX})$ and diacetoxyscirpenol (DAS) were not detected. 
Hietaniemi, V. et al. Contents of trichothecenes in oats

There are differences in susceptibility to Fusarium contamination amongst the various types of grain. Oats are regarded as being more susceptible to Fusarium fungi in Nordic countries, although studies done in Norway (Langseth et al. 2001) suggest that contamination in barley and wheat occurs just as frequently. The species prevalent here and in the other Nordic countries is F. avenaceum, which does not produce DON and becomes especially abundant during rainy, cool summers, such as in 1998. According to Marasas et al. (1984) and Eriksen and Alexander (1998) high temperatures during the growing season favour significant toxin formulators; in particular, F. culmorum, F. graminearum and $F$. poae proliferate in warm temperatures, which was quite clearly found in Finland in the year 2001 and 2002. A belated harvest increases the growth of Fusarium fungi and toxinrelated risk along with the rise in moisture. Fusarium fungi form toxins during the growing season, in warm-air drying, the fungi are preserved in grain, but trichothecene compounds no longer form under dry storage.

The aim of the present study during 19982000 was to investigate the contents of trichothecenes in representative samples of oats during official variety, nitrogen fertilization and organic farming trials in Finland, 1997-1999. Further objectives were to enhance producers procedures for growing and harvesting oats and promote industry and commerce by selection of high-quality oat varieties for various applications.

\section{Material and methods}

\section{Samples}

The oat samples were collected after harvest during official and agronomy trials conducted by MTT Agrifood Research Finland in 1997-1999. The official variety trials conducted at 8-10 locations were managed following standard pro- tocol (Fig. 1). There were 2 types of agronomy trial, the first included comparison of oat cultivars grown in conventional and organic farming systems at 6 locations, and the second used 5 nitrogen rates $\left(0,40,80,120\right.$ and $\left.160 \mathrm{~kg} \mathrm{~N} \mathrm{ha}^{-1}\right)$ with 4 oat cultivars at 2 locations (Fig. 1). More detailed information on the trials was published previously (Järvi et al. 2000, Eurola et al. 2003). After harvest, the grains were immediately dried with warm air in a flat bed grain drier to a moisture content of below $14 \%$. The oat grains were sorted with a $2.0-\mathrm{mm}$ sieve and hulled with a laboratory hulling machine BT 459 using air pressure. Oat groats were milled with a falling number hammer mill using a $1.0-\mathrm{mm}$ sieve. The total number of oat samples analysed were 147 , 147 and 99 in 1997, 1998 and 1999, respective$1 y$.

The varieties studied were Leila, Kolbu, Salo, Belinda, Veli, Roope, Aarre, Katri, Puhti and Yty. Kolbu and Roope have yellow husks, and the other varieties have white husks. Leila and Kolbu are cultivars developed in Norway, Salo and

+ Official varety trial o Nitrogen fertilization trial \# Organic cultivation trial

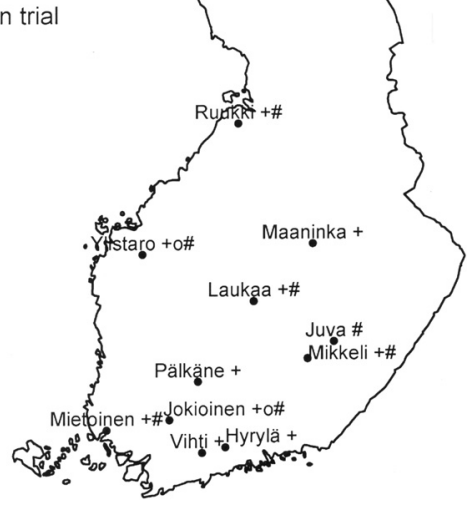

Fig. 1. Location of the trial sites in Finland. 
Vol. 13 (2004): 54-67.

Belinda in Sweden, and Veli, Roope, Aarre, Katri, Puhti and Yty in Finland. The oat varieties selected for the project included the most popular cultivars as well as new varieties on the National list of cultivars in Finland.

For example, the variety Veli was the most widely cultivated variety of oat in Finland from 1997 to 1999 . Veli gives high quantities, is early and possesses good quality. Cultivation-related reliability is favourable and the grain is whitehulled, mid-sized and rather thin-hulled. The protein content and the weight of the grain are high. Veli is a thriving variety, reliable under cultivation, that also produces good harvests during poor years. Veli is suitable as an oat for feed, food products and export. The year of $\mathrm{Na}-$ tional variety catalogue entry for this type, which was developed in Finland by Boreal Plant Breeding Ltd, was 1982.

On the other hand, Salo is a variety developed in Sweden by the Svalöf Weibull Company and emerged on the market in 1989. It has good lodging resistance and was the second most widely cultivated variety of oat in Finland from 1997 to 1999 . Salo is a late variety with large grain size, low hull content and pure resistance against dryness in addition to being susceptible to oat leaf blotch. Due to its short, durable stem, Salo withstands $10-20 \mathrm{~kg} \mathrm{ha}^{-1}$ of stronger nitrogen fertilization than normal. The main use of Salo has been as a food product.

\section{Analytical methods}

\section{Sample clean-up, identification and quantification}

To determine the presence of mycotoxins, the ground-up samples ( $25 \mathrm{~g}$ ) were extracted through a blend of acetonitrile-water (84:16) and then suction-filtered. Part of the filtrate $(7.5 \mathrm{ml})$ was extracted for activated carbon cleaning (MycoSep\#227, Romer Labs), after which the sample was transferred to a silylated test tube and evaporated to dryness under a stream of nitrogen. $100 \mu \mathrm{l} \mathrm{N}$-trimethylsilylimidazole (TMSI) reagent was added to the residue evaporated to dryness. DON, DAS, 3-acetyldeoxynivalenol (3AcDON), FX, NIV, T-2 and HT-2 toxins and 19nortestosterone (the internal standard) were identified and quantified as trimethylsilylether derivatives, employing GC-MS (Rizzo et al. 1986, Hietaniemi and Kumpulainen 1991, Saastamoinen and Saloniemi 1997).

\section{Quality assurance}

The reliability of the GC-MS method in trichothecene analysis was examined in repeatability, reproducibility, recovery and intercalibration studies by specifying the linearity of the method, the minimum detectable concentrations (quantification limit), utilizing certified reference materials and participating in FAPAS round tests. The recoveries for the compounds varied between $70-100 \%$ and the repeatability between $5 \%$ and $25 \%$, while the minimum detectable concentrations were $50 \mu \mathrm{g} \mathrm{kg}^{-1}$ with all trichothecenes. The various linearity areas with respect to trichothecenes were as follows: DON (25-8000 $\left.\mu \mathrm{g} \mathrm{kg}^{-1}\right)$, DAS (25-500 $\left.\mu \mathrm{g} \mathrm{kg}^{-1}\right), 3-$ AcDON (25-800 $\left.\mathrm{g} \mathrm{kg}^{-1}\right)$, FX (25-250 $\left.\mu \mathrm{g} \mathrm{kg}^{-1}\right)$, NIV (25-400 $\left.\mu \mathrm{g} \mathrm{kg}^{-1}\right), \mathrm{T}-2\left(25-600 \mu \mathrm{g} \mathrm{kg}^{-1}\right)$ and HT-2 (25-1300 $\left.\mathrm{g} \mathrm{kg}^{-1}\right)$. BCR wheat flour, CRM 379 was employed as the reference material (DON concentration $670 \mu \mathrm{g} \mathrm{kg}^{-1}$ ). The Chemistry Laboratory of Agrifood Research Finland follows a quality control system in accordance with ISO 17025. In the case of samples whose concentration level was below the limit of quantification, the value reported in the mean value, median and standard deviation calculations was estimated as $50 \%$ of the quantification limit.

For statistical analyses Data Desk 6.1.1 (Data exploration and visualization) was used (Velleman and Hoaglin 1981).

\section{Results and discussion}

\section{Official variety trials}

The results of the official variety trials showed that the mycotoxin DON was found most fre- 
Hietaniemi, V. et al. Contents of trichothecenes in oats

quently in Finnish oats during 1997-1999. In 1997, the procent of positive toxin findings out of all oat samples studied (51) were as follows: DON 69\%, DAS not detected, 3-AcDON 6\%, FX not detected, NIV $14 \%$, T-2 toxin $4 \%$ and HT-2 toxin $4 \%$. The mean DON concentration of all samples was $222 \mu \mathrm{g} \mathrm{kg}^{-1}$ (median $79 \mu \mathrm{g} \mathrm{kg}^{-1}$, standard deviation $\left.206 \mu \mathrm{g} \mathrm{kg}^{-1}\right)$. A few individual, rather high contents of NIV were found within a range of $<50-575 \mu \mathrm{g} \mathrm{kg}^{-1}$. The mean T-2- and HT-2 toxin concentrations were below the quantification limit of $50 \mu \mathrm{g} \mathrm{kg}^{-1}$. The highest mean DON concentrations were determined in the areas of Hyrylä, Pälkäne, Mikkeli and Laukaa
(Fig. 1). The mean contents of DON, amount of precipitation, effective temperature sum values, and $\mathrm{pH}$ and the type of soil as obtained for May - August are presented in Table 1. None of the above-mentioned background factors did not explain directly the higher toxin concentrations in these areas. The amounts of precipitation and effective temperature sums were similar to the average values observed in other areas, and not even the soil types could indicate a direct connection with elevated toxin concentrations (Table 1). The varieties, Leila, Salo, Veli, Belinda, Kolbu and Roope, were employed in the official trials. Figure 2 shows DON contents of six oat

Table 1. Precipitation, effective temperature sum, soil pH, soil type and mean deoxynivalenol (DON) content of oats in official variety trials during 1997-1999 at different trial locations in Finland.

\begin{tabular}{|c|c|c|c|c|c|c|}
\hline Location & Year & $\begin{array}{l}\text { Precipitation } \\
\text { May-Augmm }\end{array}$ & $\begin{array}{c}\text { Effective } \\
\text { temperature sum }\end{array}$ & Soil pH & Soil type & $\begin{array}{c}\text { Mean DON } \\
\text { content } \mu \mathrm{gkg}^{-1}\end{array}$ \\
\hline \multirow[t]{3}{*}{ Jokioinen } & 1997 & 302 & 1217 & 6.3 & sandy clay & 64 \\
\hline & 1998 & 318 & 1011 & 5.8 & clay & $<50$ \\
\hline & 1999 & 146 & 1184 & 5.7 & sandy clay & 243 \\
\hline \multirow[t]{3}{*}{ Mietoinen 1} & 1997 & 232 & 1285 & 5.3 & clay & 87 \\
\hline & 1998 & 245 & 1036 & 5.9 & sandy clay & 97 \\
\hline & 1999 & 92 & 1236 & 5.8 & sandy clay & 262 \\
\hline \multirow[t]{2}{*}{ Hyrylä } & 1997 & not available & not available & 6.3 & sandy clay loam & 630 \\
\hline & 1998 & not available & not available & 6.0 & coarse silt & 114 \\
\hline \multirow[t]{3}{*}{ Pälkäne } & 1997 & 253 & 1250 & 5.7 & fine silt & 334 \\
\hline & 1998 & 339 & 1043 & 6.0 & fine silt & $<50$ \\
\hline & 1999 & 141 & 1231 & 5.9 & fine silt & 184 \\
\hline \multirow[t]{3}{*}{ Mikkeli/Juva } & 1997 & 115 & 1150 & 6.9 & fine sand & 272 \\
\hline & 1998 & 337 & 976 & 6.0 & fine sand & $<50$ \\
\hline & 1999 & 243 & 1133 & 6.0 & fine sand & $<50$ \\
\hline \multirow[t]{3}{*}{ Maaninka } & 1997 & 177 & 1153 & 5.8 & coarse silt & 233 \\
\hline & 1998 & 340 & 938 & 6.1 & coarse silt & 165 \\
\hline & 1999 & 183 & 1134 & 5.5 & coarse silt & 286 \\
\hline \multirow[t]{3}{*}{ Laukaa } & 1997 & 182 & 1146 & 6.0 & coarse silt & 435 \\
\hline & 1998 & 345 & 916 & 6.0 & coarse silt & 419 \\
\hline & 1999 & 175 & 1112 & 6.0 & coarse silt & 88 \\
\hline \multirow[t]{3}{*}{ Ylistaro 1} & 1997 & 155 & 1143 & 6.0 & sandy clay loam & $<50$ \\
\hline & 1998 & 372 & 937 & 6.2 & silty clay & $<50$ \\
\hline & 1999 & 120 & 1062 & 6.1 & silty clay & $<50$ \\
\hline \multirow[t]{3}{*}{ Ylistaro 2} & 1997 & 155 & 1143 & 5.3 & mould & $<50$ \\
\hline & 1998 & 372 & 937 & 5.7 & mould & $<50$ \\
\hline & 1999 & 120 & 1062 & 5.5 & mould & 82 \\
\hline Ruukki 1 & 1999 & 182 & 952 & 5.4 & coarse silt & 102 \\
\hline Ruukki 2 & 1999 & 182 & 952 & 5.4 & mould & $<50$ \\
\hline \multirow[t]{2}{*}{ Vihti } & 1998 & 389 & 997 & 5.9 & coarse silt & 70 \\
\hline & 1999 & 132 & 1173 & 6.2 & clay & 260 \\
\hline
\end{tabular}


Vol. 13 (2004): 54-67.

DON contents $[\mu \mathrm{g} / \mathrm{kg}]$ of six oat cultivars in 1997

\begin{tabular}{|c|c|c|c|c|c|c|}
\hline Oat cultivar & Count & Mean & Median & StdDev & Min & $\operatorname{Max}$ \\
\hline Belinda & 9 & 207 & 73 & 205 & 25 & 534 \\
\hline Kolbu & 8 & 178 & 189 & 151 & 25 & 345 \\
\hline Leila & 9 & 219 & 75 & 211 & 25 & 573 \\
\hline Roope & 8 & 193 & 170 & 183 & 25 & 419 \\
\hline Salo & 8 & 297 & 290 & 252 & 25 & 706 \\
\hline Veli & 9 & 237 & 79 & 252 & 25 & 705 \\
\hline
\end{tabular}

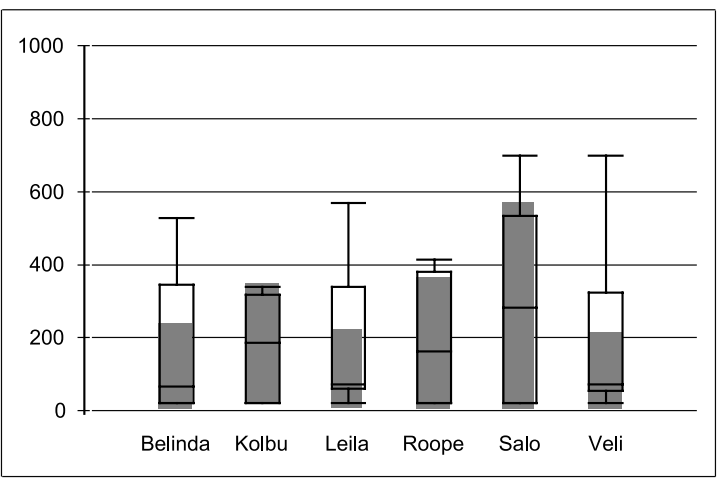

DON contents $[\mu \mathrm{g} / \mathrm{kg}]$ of six oat cultivars in 1998

\begin{tabular}{|c|c|c|c|c|c|c|}
\hline Oat cultivar & Count & Mean & Median & StdDev & Min & $\operatorname{Max}$ \\
\hline Belinda & 10 & 85 & 25 & 118 & 25 & 312 \\
\hline Kolbu & 5 & 64 & 25 & 54 & 25 & 132 \\
\hline Leila & 10 & 45 & 25 & 39 & 25 & 146 \\
\hline Roope & 7 & 29 & 25 & 12 & 25 & 56 \\
\hline Salo & 10 & 172 & 25 & 277 & 25 & 896 \\
\hline Veli & 10 & 157 & 25 & 232 & 25 & 756 \\
\hline
\end{tabular}

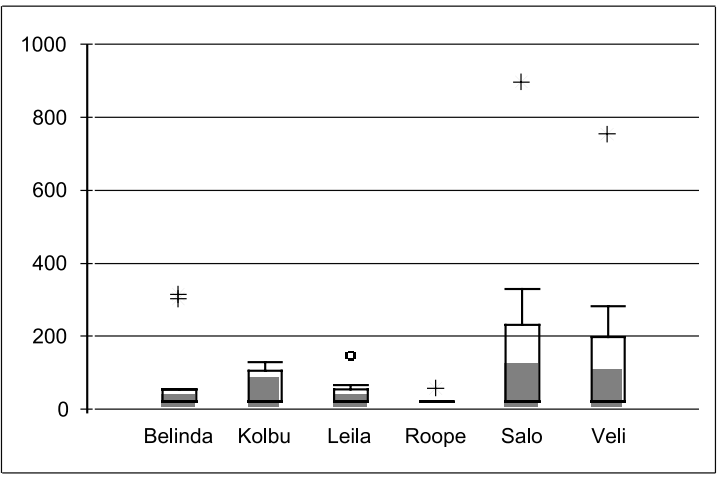

DON contents $[\mu \mathrm{g} / \mathrm{kg}]$ of six oat cultivars in 1999

\begin{tabular}{|c|c|c|c|c|c|c|}
\hline Oat cultivar & Count & Mean & Median & StdDev & Min & $\operatorname{Max}$ \\
\hline Belinda & 6 & 104 & 62 & 104 & 25 & 292 \\
\hline Kolbu & 8 & 172 & 67 & 233 & 25 & 660 \\
\hline Leila & 13 & 172 & 91 & 168 & 25 & 510 \\
\hline Roope & 6 & 157 & 167 & 86 & 25 & 287 \\
\hline Salo & 13 & 84 & 25 & 88 & 25 & 250 \\
\hline Veli & 13 & 215 & 143 & 185 & 25 & 494 \\
\hline
\end{tabular}

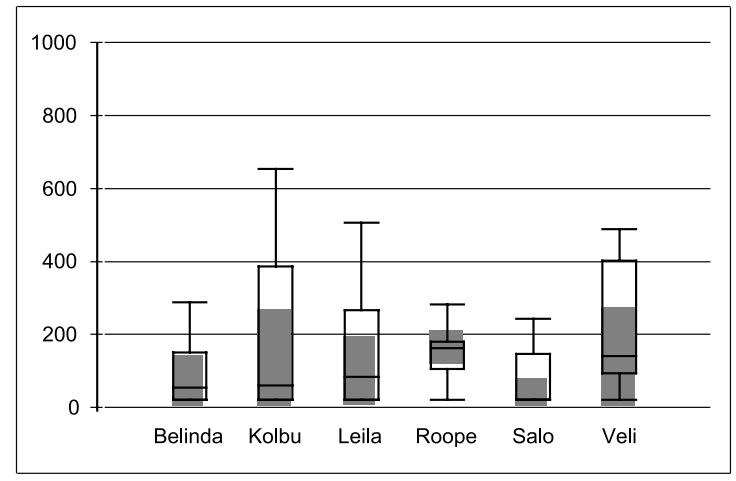

Fig. 2. Deoxynivalenol (DON) contents of six oats cultivars across all sites of official variety trials during 1997-1999 in Finland. 


\section{AGRICULTURAL AND FOOD SCIENCE}

\section{Hietaniemi, V. et al. Contents of trichothecenes in oats}

cultivars across all sites of official variety trials during 1997-1999. The highest individual DON concentrations were found in the varieties Veli and Salo. According to the statistical analyses no distinct differences were found in DON contents of various varieties. It is most likely that the climate had the greatest impact by fixing the time of heavy rainfalls in the right period of the growing season, for example during heading and harvesting time.

During these 3 research years, the lowest mycotoxin concentrations were determined from the oat harvest of 1998 (Table 2). The mean DON content from the 51 samples studied was $99 \mu \mathrm{g}$ $\mathrm{kg}^{-1}$ (median $<50 \mu \mathrm{g} \mathrm{kg}^{-1}$, standard deviation $\left.171 \mu \mathrm{g} \mathrm{kg}^{-1}\right)$. Other toxins were found in only a few samples as small concentrations, e.g., no T2 toxin content exceeding the quantification limit was found and only one HT-2 toxin concentration in excess of the quantification limit was determined. Summer 1998 was cool and rainy throughout the Finland. Despite this, conditions for the formation of toxins were not favourable. Nevertheless, fusarium head blight visibly appeared in Finnish grain, especially in rye. In the investigations of Eskola et al. (2000 and 2001) a lot of mouldiness of the Finnish grain in 1998 was found. Despite of the heavy contamination of the moulds, contents of trichothecenes were low. The findings in 1998 also indicated that Veli and Salo had the highest individual DON concentrations. The highest DON concentrations were detected in Laukaa, central Finland, where rainfall was also high and the effective temperature sum was low. However, similar amounts of rain were also observed in other areas, and there was no association with elevated toxin concentrations within the same area (Table 1).

As a research year 1999 was quite similar to 1997 (Table 2). In several areas, 1999 was clearly less subject to rain, but the effective temperature sums were similar to those in 1997. The average DON concentrations for the oat samples were, $154 \mu \mathrm{g} \mathrm{kg}^{-1}$, and the number of positive findings out of the 59 samples studied was 37 . The largest DON concentrations were detected in the variety Veli. As in 1998, no positive T-2 toxin results were measured, but 4 positive HT2 toxin contents were found, the highest value being $240 \mu \mathrm{g} \mathrm{kg}^{-1}$. NIV was found from 14 samples out of a total number of 59, with the concentrations ranging $<50-423 \mu \mathrm{g} \mathrm{kg}^{-1}$. From the regional stand point, the most contaminated oat samples were found in southern, southwestern and eastern Finland (Fig. 1). The most precipitation occurred in eastern Finland within a range of 183-243 mm, and the least was measured in southwestern Finland at $92 \mathrm{~mm}$. The year 1999 also indicated that a direct connection between the amounts of rain, effective temperature sums and contents of mycotoxins does not exist.

It still appears more probable that the 'right' period of rainfall during the growing season exerts greater significance. For example, if heavy rainfalls occurred during heading and harvesting time, the risk of growth of Fusarium fungi and production of toxins would exist. Oldenburg et al. (2000) studied the factors which influence most the infection of grain, especially wheat. The authors found the climate to have the greatest impact, followed by infection pressure/tillage, corn as preceding crop, plant protection, cultivars and plant nutrition. Langseth et al. (2001) reported from Norway that the DON level was especially high in 1988 and 1992, years with spring drought and much precipitation in July in the period during and after anthesis. According to McMullen et al. (1997) during the last two decades fusarium head blight disease occurs especially during rainy flowering seasons of the crop and besides of DON, an infection of the head by Fusarium can lead to severe yield loss and reduced kernel quality. On the other hand, rains occurring at harvest time may increase the risk of appearance of mycotoxins considerably. However, warm-air-drying as primarily employed in Finland is evidently a security-enhancing factor with respect to grain (Jayas and White 2003).

\section{Nitrogen fertilization trial}

Nitrogen fertilization trials at five nitrogen levels $0,40,80,120$ and $160 \mathrm{~kg} \mathrm{~N} \mathrm{ha}^{-1}$ were imple- 
Vol. 13 (2004): 54-67.

Table 2. Mean contents of trichothecenes in oats during official variety trials in Finland, 1997-1999.

\begin{tabular}{|c|c|c|c|c|c|c|c|}
\hline & & Number of samples & Range $\mu \mathrm{gkg}^{-1}$ & Mean $\mu \mathrm{gkg}^{-1}$ & Median $\mu \mathrm{gkg}^{-1}$ & StdDev $\mu \mathrm{gkg}^{-1}$ & Positive [\%] \\
\hline \multirow[t]{7}{*}{1997} & DON & 51 & $<50-706$ & 222 & 79 & 206 & 69 \\
\hline & DAS & 51 & Not detected & & & & \\
\hline & 3-AcDON & 51 & $<50-219$ & $<50$ & $<50$ & 41 & 6 \\
\hline & $\mathrm{F}-\mathrm{X}$ & 51 & Not detected & & & & \\
\hline & NIV & 51 & $<50-575$ & 74 & $<50$ & 129 & 14 \\
\hline & $\mathrm{T}-2$ & 51 & $<50-349$ & $<50$ & $<50$ & 62 & 4 \\
\hline & HT-2 & 51 & $<50-507$ & $<50$ & $<50$ & 85 & 4 \\
\hline \multirow[t]{7}{*}{1998} & DON & 52 & $<50-896$ & 99 & $<50$ & 171 & 33 \\
\hline & DAS & 52 & Not detected & & & & \\
\hline & 3-AcDON & 52 & $<50-310$ & $<50$ & $<50$ & 50 & 10 \\
\hline & F-X & 52 & Not detected & & & & \\
\hline & NIV & 52 & $<50-530$ & 53 & $<50$ & 95 & 10 \\
\hline & $\mathrm{T}-2$ & 52 & Not detected & & & & \\
\hline & HT-2 & 52 & $<50-116$ & & & & 2 \\
\hline \multirow[t]{7}{*}{1999} & DON & 59 & $<50-660$ & 154 & 108 & 158 & 63 \\
\hline & DAS & 59 & Not detected & & & & \\
\hline & 3-AcDON & 59 & Not detected & & & & \\
\hline & $\mathrm{F}-\mathrm{X}$ & 59 & Not detected & & & & \\
\hline & NIV & 59 & $<50-423$ & $<50$ & $<50$ & 63 & 24 \\
\hline & $\mathrm{T}-2$ & 59 & Not detected & & & & \\
\hline & HT-2 & 59 & $<50-240$ & $<50$ & $<50$ & $<50$ & 7 \\
\hline
\end{tabular}

mented. Aarre, Katri, Kolbu and Salo were the varieties used in the trials, which were carried out in 2 locations: in Jokioinen, province of Häme and Ylistaro, South Ostrobothnia (Fig. 1). The results showed that the use of various nitrogen fertilization levels during 1997-1999 only slightly affected the mycotoxin concentrations (Fig. 3). The highest mean DON concentrations were observed in the data from 1999 within a range of 101-730 $\mu \mathrm{g} \mathrm{kg}^{-1}$ (Fig. 3). The DON concentrations in Häme (Jokioinen) were, to some extent, higher than those in South Ostrobothnia (Ylistaro), although the amounts of rainfall were similar. No remarkable differences between the various varieties were found; the highest individual concentrations were determined from the variety Aarre (Fig. 3). Aarre is an early, highyielding and high-quality oat variety and in addition has good lodging resistance. It is earlier than Veli by one day. Aarre is used for feed and food products and export and it is developed by
Boreal Plant Breeding Ltd of Finland. It was introduced in the National variety catalogue in 1995.

\section{Organic farming}

The trials for conventional as well as organic cultivation were implemented during 1997-1998 at 6 locations: Jokioinen, Mietoinen, Laukaa, Partala, Ylistaro and Ruukki. Only at the Partala Research Station in eastern Finland was conventional cultivation not used as comparative data. More precise comparison of these cultivation methods could be carried out only with 2 varieties, Veli and Puhti, although 5 other varieties Aarre, Katri, Kolbu, Leila and Roope were also included in the organic cultivation trials. In contrast to the results obtained in the official variety trials and nitrogen fertilization trials, DON was also the most commonly appearing myco- 


\section{AGRICULTURAL AND FOOD SCIENCE}

\section{Hietaniemi, V. et al. Contents of trichothecenes in oats}

Mean DON contents $[\mu \mathrm{g} / \mathrm{kg}]$ at five nitrogen levels in oats cultivar Aarre

\begin{tabular}{|c|c|c|c|c|c|c|c|c|c|c|}
\hline N level [kg/ha] & Count & Mean & Min & $\operatorname{Max}$ & \multirow{2}{*}{$\begin{array}{l}800 \\
600\end{array}$} & & \multirow{2}{*}{$T$} & & & \\
\hline 0 & 2 & 492 & 322 & 662 & & 7 & & & & \\
\hline & & & & $\ldots$ & \multirow{2}{*}{400} & & & & & \\
\hline 40 & 2 & 510 & 289 & 730 & & & & & + & + \\
\hline 80 & 2 & 354 & 101 & 607 & 200 & & & & & \\
\hline 120 & 2 & 432 & 354 & 509 & \multirow{2}{*}{0} & & & & & \\
\hline & & & & & & 0 & 40 & 80 & 120 & 160 \\
\hline 160 & 2 & 428 & 328 & 528 & \multicolumn{6}{|c|}{$N$ [kg/ha] } \\
\hline
\end{tabular}

Mean DON contents $[\mu \mathrm{g} / \mathrm{kg}]$ at five nitrogen levels in oats cultivar Katri

\begin{tabular}{|c|c|c|c|c|c|c|c|c|c|c|}
\hline N level [ $\mathrm{kg} / \mathrm{ha}]$ & Count & Mean & Min & $\operatorname{Max}$ & 800 & & & & & \\
\hline 0 & 2 & 314 & 207 & 421 & 600 & & & & & \\
\hline 40 & 2 & 429 & 252 & 606 & 400 & & & & & 7 \\
\hline 80 & 2 & 344 & 194 & 493 & 200 & & & & $\perp$ & \\
\hline 120 & 2 & 364 & 232 & 496 & \multirow{2}{*}{0} & & & & & \\
\hline \multirow[b]{2}{*}{160} & \multirow[b]{2}{*}{2} & \multirow[b]{2}{*}{335} & \multirow[b]{2}{*}{194} & \multirow[b]{2}{*}{476} & & 0 & 40 & 80 & 120 & 160 \\
\hline & & & & & \multicolumn{6}{|c|}{$\mathrm{N}[\mathrm{kg} / \mathrm{ha}]$} \\
\hline
\end{tabular}

Mean DON contents [ $\mu \mathrm{g} / \mathrm{kg}]$ at five nitrogen levels in oats cultivar Kolbu

\begin{tabular}{|c|c|c|c|c|c|c|c|c|c|c|}
\hline Nlevel $[\mathrm{kg} / \mathrm{ha}]$ & Count & Mean & Min & $\operatorname{Max}$ & \multicolumn{6}{|c|}{800 十 } \\
\hline 0 & 2 & 358 & 328 & 387 & 600 & & & & & \\
\hline \multirow{2}{*}{40} & \multirow{2}{*}{2} & \multirow{2}{*}{340} & \multirow{2}{*}{174} & \multirow{2}{*}{505} & \multirow{2}{*}{400} & \multirow{3}{*}{ 王 } & & $T$ & & \multirow[b]{2}{*}{$\equiv$} \\
\hline & & & & & & & & & & \\
\hline 80 & 2 & 302 & 171 & 433 & 200 & & & & 1 & \\
\hline 120 & 2 & 265 & 152 & 378 & 0 & & & & & \\
\hline \multirow[b]{2}{*}{160} & \multirow[b]{2}{*}{2} & \multirow[b]{2}{*}{337} & \multirow[b]{2}{*}{319} & \multirow[b]{2}{*}{355} & & 0 & 40 & 80 & 120 & 160 \\
\hline & & & & & \multicolumn{6}{|c|}{$N$ [kg/ha] } \\
\hline
\end{tabular}

Mean DON contents $[\mu \mathrm{g} / \mathrm{kg}]$ at five nitrogen levels in oats cultivar Salo

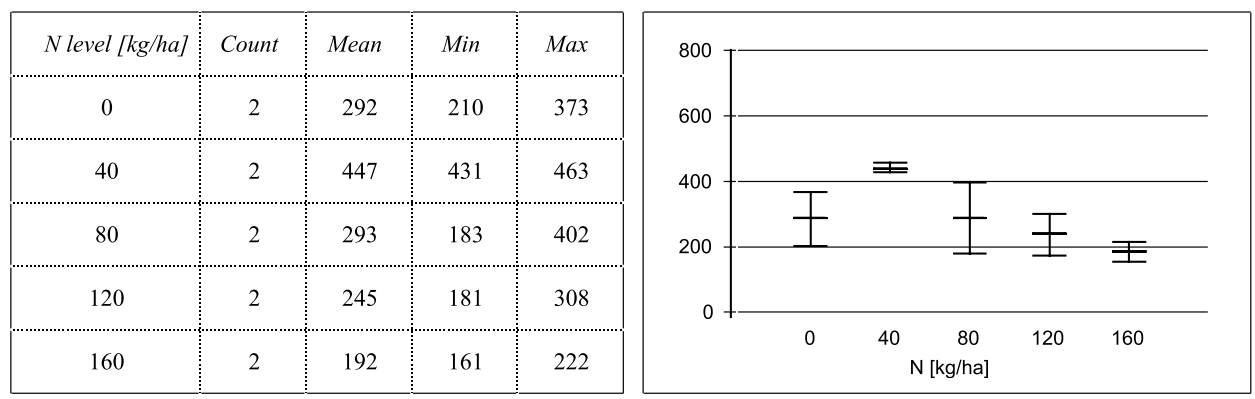

Fig. 3. Mean deoxynivalenol (DON) contents at five nitrogen levels in nitrogen fertilization trials in 1999 in Finland at two sites (Jokioinen and Ylistaro). 


\section{AGRICULTURAL AND FOOD SCIENCE}

Vol. 13 (2004): 54-67.

DON contents $[\mu \mathrm{g} / \mathrm{kg}]$ in conventionally cultivated oats in 1997

\begin{tabular}{|c|c|c|c|c|c|c|}
\hline Location & Count & Mean & Median & StdDev & Min & $\operatorname{Max}$ \\
\hline Jokioinen & 2 & 75 & & & 68 & 81 \\
\hline Laukaa & 2 & 526 & & & 403 & 648 \\
\hline Mietoinen & 2 & 295 & & & 289 & 300 \\
\hline Partala * & 0 & - & & & $\infty$ & $-\infty$ \\
\hline Ruukki & 2 & 266 & & & 264 & 268 \\
\hline Ylistaro & 2 & 47 & & & 25 & 69 \\
\hline
\end{tabular}

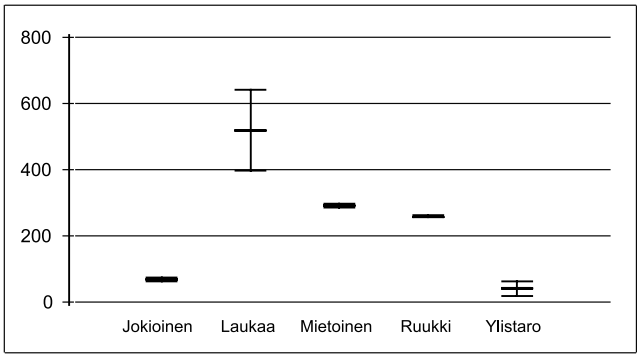

DON contents $[\mu \mathrm{g} / \mathrm{kg}]$ in organically cultivated oats in 1997

\begin{tabular}{|c|c|c|c|c|c|c|}
\hline Location & Count & Mean & Median & StdDev & Min & $\operatorname{Max}$ \\
\hline Jokioinen & 8 & 50 & 61 & 21 & 25 & 69 \\
\hline Laukaa & 8 & 100 & 25 & 141 & 25 & 370 \\
\hline Mietoinen & 8 & 345 & 316 & 81 & 258 & 474 \\
\hline Partala & 7 & 25 & 25 & 0 & 25 & 25 \\
\hline Ruukki & 7 & 315 & 318 & 127 & 66 & 455 \\
\hline Ylistaro & 8 & 30 & 25 & 14 & 25 & 63 \\
\hline
\end{tabular}

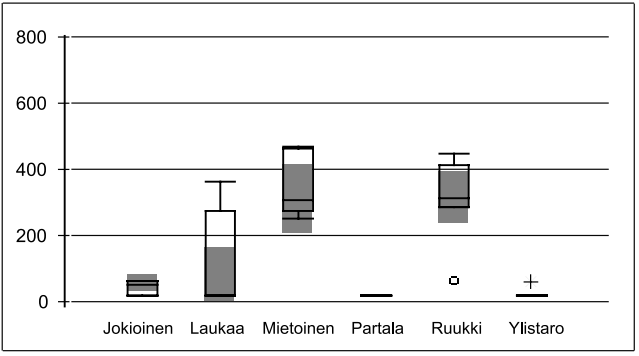

DON contents $[\mu \mathrm{g} / \mathrm{kg}]$ in conventionally cultivated oats in 1998

\begin{tabular}{|c|c|c|c|c|c|c|}
\hline Location & Count & Mean & Median & StdDev & Min & $\operatorname{Max}$ \\
\hline Jokioinen & 2 & 25 & & & 25 & 25 \\
\hline Laukaa & 2 & 25 & & & 25 & 25 \\
\hline Mietoinen & 2 & 131 & & & 25 & 237 \\
\hline Partala * & 0 & - & & & $\infty$ & $-\infty$ \\
\hline Ruukki & 2 & 57 & & & 25 & 88 \\
\hline Ylistaro & 2 & 25 & & & 25 & 25 \\
\hline
\end{tabular}

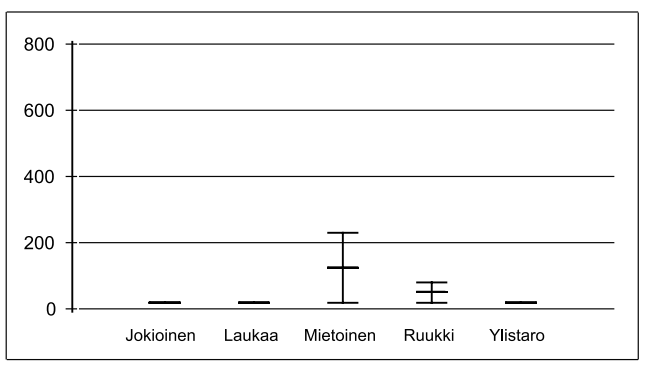

DON contents [ $\mu \mathrm{g} / \mathrm{kg}]$ in organically cultivated oats in 1998

\begin{tabular}{|c|c|c|c|c|c|c|}
\hline Location & Count & Mean & Median & StdDev & Min & $\operatorname{Max}$ \\
\hline Jokioinen & 8 & 56 & 25 & 53 & 25 & 168 \\
\hline Laukaa & 7 & 97 & 103 & 63 & 25 & 210 \\
\hline Mietoinen & 8 & 97 & 59 & 94 & 25 & 286 \\
\hline Partala & 7 & 25 & 25 & 0 & 25 & 25 \\
\hline Ruukki & 7 & 124 & 108 & 101 & 25 & 324 \\
\hline Ylistaro & 8 & 43 & 25 & 32 & 25 & 97 \\
\hline
\end{tabular}

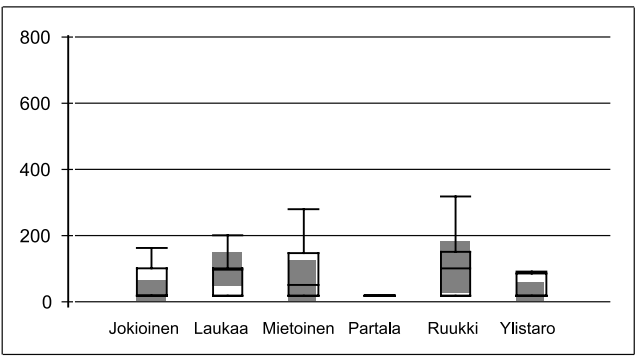

* The results of the conventional cultivation trials at Partala Research Station were not available.

Fig. 4. Mean deoxynivalenol (DON) contents in oats during organic and conventional cultivation trials in Finland in 1997 and 1998. 


\section{AGRICULTURAL AND FOOD SCIENCE}

\section{Hietaniemi, V. et al. Contents of trichothecenes in oats}

toxin in samples from the conventional and organic cultivation trials (Fig. 4). Correspondingly, the results corroborated previous indications that the toxin concentrations during the rainy, cold year of 1998 were clearly lower than in 1997. There were no large differences in DON concentrations in the cultivation methods studied. The mean levels appeared to be similar in organic and conventional cultivation (Fig. 4).

According to Leblanc et al. (2002) a particular group at risk for exposure to DON may be the consumers of organic products as they may regularly eat foods containing higher levels of DON than the general population. On the basis of the work of Schollenberger (2002) the DON content of flour samples originating from conventionally produced wheat was significantly higher than that of samples from organic production. Similar results were obtained by Döll et al. (2000) and Usleber et al. (2000), who found lower DON contents in wheat, rye and flour samples of organic origin than in those from conventional production. In agreement with this study, Marx et al. (1995) reported from southern Germany that the incidence of DON in conventionally and organically produced wheat was $88 \%$ and $76 \%$, whereas the mean contents were 420 and $486 \mu \mathrm{g} \mathrm{kg}^{-1}$, respectively. In addition, according to Döll et al. (2000) the organic farming system with the practice of a well-balanced crop rotation, tillage and fertilization showed benefits concerning the contamination with Fusarium toxins, especially DON.

\section{Conclusions}

The results of the official variety and nitrogen fertilization trials and comparison of conventional and organic cultivation, suggest that future research and follow-up on trichotecenes must be emphasized and continued. The results of the trials showed that the mycotoxin DON was found most frequently in Finnish oats during 19971999. According to the results on an average 55\% of the oat samples respective to the official variety trials in 1997-1999 contained DON within the range of $50-896 \mu \mathrm{g} \mathrm{kg}^{-1}$. Correspondingly, the range and frequencies of other toxin findings were as follows: 3-AcDON 50-310 $\mu \mathrm{g} \mathrm{kg}^{-1}$ (5\%), NIV 50-575 $\mathrm{g} \mathrm{kg}^{-1}$ (16\%), T-2 toxin 50$349 \mu \mathrm{g} \mathrm{kg}^{-1}(1 \%)$ and HT-2 toxin 50-507 $\mu \mathrm{g} \mathrm{kg}$ ${ }^{1}(4 \%)$. A directive currently under preparation in the European Union will specify the tolerance limits for DON (1500 $\left.\mu \mathrm{g} \mathrm{kg}^{-1}\right)$. In comparison to previous studies, the contents of trichothecenes in grains appeared similar or lower to those reported earlier in the Northern or Southern Hemisphere (Karppanen et al. 1985, Tanaka et al. 1988, Hietaniemi and Kumpulainen 1991, Müller and Schwadorf 1993, Rizzo 1993, Pettersson et al. 1995, Groves et al. 1999, Janardhana et al. 1999, Döll et al. 2000, Langseth and Rundberget 2001, Rizzo et al. 2001, Eskola 2002, Schollenberger et al. 2002, Salay and Mercadante 2002). The results also showed that no distinct differences were found in DON contents of various varieties. The differences in DON concentrations between organic and conventional cultivation were small. In addition, the results showed that the use of various nitrogen fertilization levels only slightly affected the trichothecene concentrations.

Nevertheless, the importance of background factors with respect to samples is often forgotten in monitoring the quality of grains, not to mention a deeper familiarity with their impact and, through the same, better control over grain quality. Evidently, the incidence of rain during heading time represents a risk factor (McMullen et al. 1997, Döll et al. 2000, Oldenburg et al. 2000, Langseth et al. 2001), although it has not been indicated here. The present results also showed that more precise research into the effects of cultivation methods in relation to fungi and toxins is necessary (Norred 2000). Good familiarity with, the effects of the preceding crop, rotation, seed purity, various soil preparation methods, direct sowing and pesticides on the formation of mycotoxins is a minimal requirement. A question of its own right also concerns breeding for resistance against Fusarium fungi 
Vol. 13 (2004): 54-67.

and their associated toxins (de Vries 2000, Hollins et al. 2003). Knowledge of these factors is a prerequisite for good cultivation-related directives that industry and farmers should follow to ensure high-quality production of oats both in Finland and internationally.

Acknowledgements. The authors wish to thank Ms. Kirsi Puisto, Ms. Leena Holkeri, Mr. Seppo Nummela and Mr. Tauno Koivisto for their skilful technical assistance and enthusiasm for this study. This study was financially supported by the Ministry of Agriculture and Forestry and the Finnish food and feed industry: Raisio Group, Suomen Viljava Ltd. and Kemira Agro Ltd.

\section{References}

Atroshi, F., Rizzo, A., Westermarck, T. \& Ali-Vehmas, T. 2002. Antioxidant nutrients and mycotoxins. Toxicology 180: 151-167.

Creppy, E.E. 2002. Update of survey, regulation and toxic effects of mycotoxins in Europe. Toxicology Letters 127, 1-3: 19-28.

de Vries, G.E. 2000. New Canadian barley nursery. Trends in Plant Science 5, 11: 462.

de Vries, J.W., Trucksess, M.W. \& Jackson, L.S. 2003. Mycotoxins and food safety. Trends in Food Science \& Technology 14: 111-115.

Döll, S, Valenta, H., Dänicke, S. \& Flachowsky, G. 2002. Fusarium mycotoxins in conventionally and organically grown grain from Thuringia/Germany. Landbauforschung Völkenrode 52: 91-96.

Egmond, Van, H.P. 1989. Current situation on regulations of mycotoxins. Overview of tolerances and status of standard methods of sampling and analysis. Food Additives and Contaminants 6: 139-188.

Eriksen, G.S. \& Alexander, J. (eds.). 1998. Fusarium toxins in cereals - a risk assessment. TemaNord 1998: 502. Nordic Council of Ministers. Copenhagen, Denmark. 146 p.

Eskola, M. 2002. Study on trichothecenes, zearalenone and ochratoxin $A$ in Finnish cereals: occurrence and analytical techniques. EELA publications 3. National Veterinary and Food Research Institute (EELA) and University of Helsinki. Helsinki, Finland. 78 p. (Academic dissertation).

Eskola, M., Parikka, P. \& Rizzo, A. 2001. Trichothecenes, ochratoxin $A$ and zearalenone contamination and Fusarium infection in Finnish cereal samples in 1998. Food Additives and Contaminants 18: 707-718.

Eskola, M., Rizzo, A. \& Soupas, L. 2000. Occurrence and amounts of some Fusarium toxins in Finnish cereal samples in 1998. Acta Agriculturae Scandinavica., Sect. B, Soil and Plants Science 50: 183-186.
Eurola, M., Hietaniemi, V., Kontturi, M., Tuuri, H., Pihlava, J.-M., Saastamoinen, M., Rantanen, O., Kangas, A. \& Niskanen, M. 2003. Cadmium contents of oats (Avena sativa L.) in official variety, organic cultivation, and nitrogen fertilization trials during 1997-1999. Journal of Agricultural and Food Chemistry 51: 2608-2614.

Groves, F.D., Zhang, L., Chang, Y.-S., Ross, P.F., Casper, H., Norred, W.P., You, W.-C. \& Fraumeni, J.F., Jr. 1999. Fusarium mycotoxins in corn and corn products in a high-risk area for gastric cancer in Shandong province, China. Journal of AOAC International 82, 3:657662.

Gutleb, A.C., Morrison, E. \& Murk, A.J. 2002. Cytotoxicity assays for mycotoxins produced by Fusarium strains: a review. Environmental Toxicology and Pharmacology 11, 3-4: 309-320.

Hietaniemi, V. \& Kumpulainen, J. 1991. Contents of Fusarium toxins in Finnish and imported grains and feeds. Food Additives and Contaminants 8, 2: 171-182.

Hietaniemi, V. \& Kumpulainen, J. 1993. Mycotoxins in cereal grains and feeds in Finland. In: Tiina AaltoKaarlehto \& Hannu Salovaara (eds.). Proceedings from the 25th Nordic Cereal Congress: The Nordic Cereal Industry in an Integrating Europe: June 6-9 1993, Helsinki. EKT Series of the Food Science Programme, University of Helsinki 930. p. 54-59.

Hollins, T.W., Ruckenbauer, P. \& De Jong, H. Progress towards wheat varieties with resistance to fusarium head blight. Food Control 14, 4: 239-244.

Janardhana, G.R., Raveesha, K.A. \& Shekar Shetty, H. 1999. Mycotoxin contamination of maize grains grown in Karnataka (India). Food and Chemical Toxicology 37, 8: 863-868.

Järvi, A., Kangas, A., Laine, A., Niskanen, M., Salo, Y., Vuorinen, M., Jauhiainen, L. \& Mäkelä, L. 2000. Results of the official variety trials 1992-1999. Publications of Agricultural Research Centre of Finland. Serie A $70.216 \mathrm{p}$.

Jayas, D.S. \& White, N.D.G. 2003. Storage and drying of grain in Canada: low cost approaches. Food Control 14, 4: 255-261.

Joffe, A. 1978. Fusarium poae and F. sporotrichioides as principal causal agents of alimentary toxic Aleukia. In: Wyllie, T.D. \& Morehouse, L.G. (eds.). Mycotoxic fungi. Mycotoxins. Mycotoxicoses. New York and Basel: Marcel Dekker. Vol. 3. p. 21-86.

Karppanen, E., Rizzo, A., Berg, S., Lindfors, E. \& Aho, R. 1985. Fusarium mycotoxins as a problem in finnish feeds and cereals. Journal of Agricultural Science in Finland 57: 195-206.

Langseth, W., Elen, O. \& Rundberget, T. 2001. Occurrence of mycotoxins in Norwegian cereals 19881999. In: Logrieco, A. (ed.). Occurrence of toxigenic fungi and mycotoxins in plants, food and feed in Europe. p. 37-43.

Langseth, W., Ellingen, Y., Nymoen, U. \& Økland, E.M. 1989. High-performance liquid chromatographic determination of ZEN and ochratoxin A in cereals and feed. Journal of chromatography 478: 269-274.

Langseth, W. \& Rundberget, T. 1999. The occurrence of HT-2 toxin and other trichothecenes in Norwegian cereals. Mycopathologia 147: 157-165. 


\section{Hietaniemi, V. et al. Contents of trichothecenes in oats}

Leblanc, J.-C., Malmauret, L., Delobel, D. \& Verger, P. 2002. Simulation of the exposure to deoxynivalenol of French consumers of organic and conventional foodstuffs. Regulatory Toxicology and Pharmacology 36, 2: 149-154.

Le Guevel, R. \& Pakdel, F. 2001. Assessment of oestrogenic potency of chemicals used as growth promoter by in vitro methods. Human Reproduction 16: 1030-1036.

Lígia Martins, M. \& Martins, H.M. 2002. Influence of water activity, temperature and incubation time on the simultaneous production of deoxynivalenol and zearalenone in corn (Zea mays) by Fusarium graminearum. Food Chemistry 79, 3: 315-318.

McMullen, M., Jones, R. \& Gallenberg, D. 1997. Scab of wheat and barley: a re-emerging disease of devasting impact. Plant disease 81: 1340-1348.

Marasas, W.F.O., Nelson, P.E. \& Tousson, T.A. 1984. Toxigenic Fusarium species: identity and mycotoxicology. University Park, Pennsylvania State University Press. 328 p.

Marx, H., Gedek, B. \& Kollarczik, B. 1995. Vergleichende Untersuchungen zum mykotoxikologischen Status von ökologisch und konventionell angebautem $\mathrm{Ge}$ treide. Zeitschrift fur Lebensmittel-Untersuchung und Forschung 201: 83-86.

Müller, H.-M. \& Schwadorf, K. 1993. A Survey of the natural occurrence of Fusarium toxins in wheat grown in a southwestern area of Germany. Mycopathologia 120: 115-121.

Norred, W.P. 2000. Agriculturally important fungal toxins. Chemical Health and Safety 7, 4: 22-25.

Oldenburg, E., Valenta, H. \& Sator, Ch. 2000. Risikoabschätzung und Vermeidungsstrategien bei der Futtermittelerzeugung. Landbauforschung Völkenrode SH 216: 5-34.

Pettersson, H., Hedman, R., Engström, B., Elwinger, K. \& Fossum, O. 1995. Nivalenol in Swedish cereals occurrence, production and toxicity towards chickens. Food Additives and Contaminants 12, 3: 373-376.

Rizzo, A.F., Saari, L. \& Lindfors, E. 1986. Derivatization of trichothecenes and water treatment of their trimethylsilyl ethers in an anhydrous apolar solvent. Journal of chromatography 368: 381-386.

Rizzo, A. 1993. Mycotoxins in Finnish alimentary products. Environmental Health 24: 457-466.

Rizzo, A., Berg, S., Eskola, M., Perttilä, U. \& Saari, L. 2001. Occurrence of mycotoxins in cereals and foodstuffs in Finland between years 1987-1999. In: Logrieco, A. (ed.). Occurrence of toxigenic fungi and mycotoxins in plants, food and feed in Europe. p. 3743.

Rintala, R., Hirvi, T. \& Hallikainen, A. 1995. A study on the ochratoxin $A$ and zearalenone (F2) concentrations in bread corn and animal feed corn samples in 19921994, and the ochratoxin A concentrations in samples of animal origin in 1994. National Food Administration Research Notes 8/1995. Helsinki. 19 p.

Saastamoinen, I. \& Saloniemi, H. 1997. Quantification and confirmation of trichothecenes by gas chromatography/mass spectrometry/selected ion monitoring. In: Proceedings of the 9th International congress in animal hygiene, ISAH-97. Poster abstract. p. 937940.

Salay, E. \& Mercadante, A.Z. 2002. Mycotoxins in Brazilian corn for animal feed: occurrence and incentives for the private sector to control the level of contamination. Food Control 13, 2: 87-92.

Schollenberger, M., Jara, H.T., Suchy, S., Drochner, W. \& Müller, H.-M. 2002. Fusarium toxins in wheat flour collected in an area in southwest Germany. International Journal of Food Microbiology 72, 1-2: 85-89.

Scott, P.M. 1989. The natural occurrence of trichothecenes. In: Beasley, V.R. (ed.). Trichothecene mycotoxicosis: pathophysiologic effects. Boca Raton: CRC Press. Vol. 1. p. 1-26.

Scott, P.M. 1991. Possibilities of reduction or elimination of mycotoxins present in cereal grains. In: Chelkowski, J. (ed.). Cereal grain. Mycotoxins, fungi and quality in drying and storage. Elsevier, Amsterdam. p. 529572.

Shephard, G.S., Thiei, P.G., Stockenström, S. \& Sydenham, E.W. 1996. Worldwide survey of fumonisin contamination of corn and corn-based products. Journal of AOAC International 79, 3: 671-687.

Smith, T.K. 2003. Mycotoxin management. In: World grain. p. 29-33.

Sudakin, D.L. 2003. Trichothecenes in the environment: relevance to human health. Toxicology Letters 143, 2: 97-107.

Tanaka, T., Hasegawa, A., Yamamoto, S., Lee, U.-S., Sugiura, Y. \& Ueno, Y. 1988. Worldwide contamination of cereals by the mycotoxins nivalenol, deoxynivalenol, and zearalenone. 1: survey of 19 countries. Journal of Agricultural and Food Chemistry 36: 979983.

Thuvander, A., Möller, T., Barbieri, H.E., Jansson, A., Salomonsson, A.-C. \& Olsen, M. 2001. Dietary intake of some important mycotoxins by the Swedish population. Food Additives and Contaminants 18, 8: 696-706.

Ueno, Y. 1987. Trichothecenes in food. In: Krogh, P. (ed.). Mycotoxins in food. London, Academic Press. p. 123147.

Usleber, E., Lepschy, J. \& Märtlbauer, E. 2000. Deoxynivalenol in Mehlproben des Jahres 1999 aus dem Einzelhandel. Mycotoxin Research 16A: 30-33.

Velleman \& Hoaglin 1981. Applications, basics, and computing of exploratory data analysis. Boston, Duxbury Press, Chapter 3. 354 p.

Vilà, B., Jaradat, Z.W., Marquardt, R.R. \& Frohlich, A.A. 2002. Effect of T-2 toxin on in vivo lipid peroxidation and vitamin $\mathrm{E}$ status in mice. Food and Chemical Toxicology 40, 4: 479-486.

WHO 1993. Some naturally occurring substances: food items and constituents, heterocyclic aromatic amines and mycotoxins. IARC monographs on the evaluation of carcinogenic risks to humans 56: 397-444.

WHO 2001. Safety evaluation of certain mycotoxins in food: prepared by the fifty-sixth meeting of the joint FAO/WHO Expert Committee on Food Additives (JECFA). WHO Food Additives Series: 47. FAO Food and Nutrition Paper: 74. IPCS-International Programme on Chemical Safety, WHO Geneva, 2001. $701 \mathrm{p}$. 
Vol. 13 (2004): 54-67.

Widestrand, J. 2001. Assessment of trichothecenes contamination, chemical aspects and biological methodology. Doctoral thesis, Swedish University of Agricultural Sciences. Uppsala, Sweden. 96 p.
Ylimäki, A., Koponen, H. Hintikka, E.-L., Nummi, M., NikuPaavola, M.-L., Ilus, T. \& Enari, T.-M. 1979. Mycoflora and occurrence of Fusarium toxins in Finnish grain. Technical Research Centre of Finland, Materials and Processing Technology, Publication 21. 28 p.

\title{
SELOSTUS
}

\section{Kauran trikotekeenipitoisuus virallisissa lajikekokeissa sekä typpilannoitus- ja luomulajikekokeissa}

\author{
Veli Hietaniemi, Markku Kontturi, Sari Rämö, Merja Eurola, Arjo Kangas, Markku Niskanen ja \\ Marketta Saastamoinen \\ MTT (Maa- ja elintarviketalouden tutkimuskeskus) ja Satafood Kehittämisyhdistys ry
}

Viljojen luontaiset toksiinit, kuten hometoksiinit, ovat
tärkeitä raaka-aineen laadun mittareita elintarvike- ja
rehuteollisuuden kannalta. Tutkimuksessa määritettiin
Fusarium-toksiinit ja trikotekeenit satokausien 1997-
1999 virallisten lajike-, typpilannoitus- ja luomula-
jikekokeiden kauranäytteistä. Lisäksi tavoitteena oli
lisätä tietoa eri kauralajikkeiden kemiallisesta koos-
tumuksesta. Viralliset lajike-, typpilannoitus- ja luo-
mulajikekokeet toteutettiin MTT:n tutkimusasemilla.
Virallisten lajikekokeiden tulosten perusteella
homemyrkyistä deoksinivalenoli (DON) esiintyi
useimmiten suomalaisessa kaurassa vuosina 1997-
1999 . Tutkituista näytteistä $55 \%$ sisälsi DON:a $<50-$
896 g kg-1. Pienimmät trikotekeenipitoisuudet kol-
men tutkimusvuoden aikana määritettiin vuoden 1998
kaurasadosta. Satokausi 1998 oli hyvin sateinen, kos-
tea ja kylmä. Typpilannoituskokeissa käytettiin nel-
jää eri typpitasoa $40,80,120$ ja 160 . Lisäksi vertai-
luaineistona oli nollataso, jossa lisätyppeä ei käytet-
ty ollenkaan. Tulosten perusteella typpilannoitusta- so ei vaikuttanut kauran mykotoksiinipitoisuuksiin vuosina 1997-1999. Suurimmat keskimääräiset DON-pitoisuudet havaittiin vuoden 1999 aineistosta vaihteluvälillä $192-510 \mu \mathrm{g} \mathrm{kg}^{-1}$. Vastaavasti kuin edellä esitetyt tulokset virallisista lajikekokeista ja typpilannoituskokeista osoittivat, deoksinivalenoli oli yleisimmin esiintyvä Fusarium-toksiini myös tavanomaisen ja luomuviljelykokeiden näytteissä. Tutkittu viljelymenetelmä ei vaikuttanut DON-pitoisuuksiin.

Yhteenvetona voidaan todeta, että viljoissa esiintyviä trikotekeenejä on tärkeä tutkia lisää, ja järjestelmä pitoisuuksien seurantaan on luotava. EU:ssa valmisteilla oleva direktiivi tulee määrittämään suurimmat sallitut pitoisuudet deoksinivalenolille, T-2ja HT-2-toksiinille, tsearalenonille ja fumonisiineille. Viljanäytteiden taustatietojen tunteminen ja niiden vaikutusten analysointi nousee yhä tärkeämmäksi laadun seurannassa. Tämä mahdollistaa nykyistä paremman viljan laadun hallinnan. 